\title{
The Differential Expression and Snp Analysis of the Ovoinhibitor Gene in the Ovaries of Laying Duck Breeds (Anas Platyrhynchos)
}

-Author(s)
Wu Y',\|
Liang $H^{\prime}$
Zhang $H^{\prime}$
Pi JS'
Pan AL'
Shen J'
Pu YJ'
Du JP'
' Institute of Animal Science and Veterinary
Medicine, Hubei Academy of Agricultural
Science, Wuhan 430064, China
"Hubei Key Laboratory of Animal Embryo
and Molecular Breeding, Wuhan 430064,
China

\section{Mail Address}

Corresponding author e-mail address Jin-ping Du

South Lake Yao yuan special No. 1, Hongshan District, Wuhan, Hubei, China

Zip Code: 430064

Tel: $\quad$ +862787380190

Email: youngwuyan@163.com

\section{nKeywords}

Laying ducks (Anas platyrhynchos), laying period, gene expression, OlH, ovaries.

\section{ABSTRACT}

Ovoinhibitor $(\mathrm{OIH})$ is the main proteinase inhibitor in the egg white. In the present study, real-time quantitative PCR and Western-Blot were used to analyze different expression pattern of $\mathrm{OlH}$ in ovaries as a candidate gene of reproductive traits in Jingjiang ducks (JJ ducks) and Shaoxing ducks (SX ducks) during three laying stages. To study the polymorphism of the $\mathrm{OlH}$ gene in those two duck populations, we designed five pairs of primers to detect SNPs of exon 3-5, 5-6, 14-16 and intron 7, 9 of the $\mathrm{OIH}$ gene by polymerase chain reactionrestriction fragment length polymorphism (PCR-RFLP) and DNA pool sequencing methods. The results showed that $\mathrm{OlH}$ expression increased during the laying stage in the ovaries of both duck breeds. The relative expression levels of $\mathrm{OlH}$ in the egg at hatch and 180days of age were lower in JJ ducks than in SX ducks, but higher in JJ ducks than SX ducks at 500 days of age. Only exon 5-6 locus had a novel SNP. One variation $(389 \mathrm{G}>\mathrm{A}$ ) was detected in the two tested duck populations and it was associated with some laying traits, such as body weight of hatch, age at first egg, weight at first egg, egg number at 72 weeks of age. The AG genotype was associated with inferior body weight of hatch and superior weight at first egg, age at first egg and egg number at 72 weeks of age. Therefore, these results suggest that OIH may be a strong candidate gene related to some laying traits in ducks.

\section{INTRODUCTION}

Ovoinhibitor $(\mathrm{OIH})$ is the main proteinase inhibitor in the albumen (Kinoshita et al., 2004). It is produced in the tubular gland cell of the oviduct, which is regulated by estrogen and progesterone (Liu et al., 1971). It has a broad inhibitory activity of other proteinases present in the blood plasma and in the egg white of chickens (Laskowski \& Kato, 1980). Słowińska et al. (2014) reported that the ovoinhibitor in the turkey reproductive tract maintains a microenvironment for the sperm in the epididymis and ductus deferens. Gao et al.(2016) reported that protease inhibitors, such as ovoinhibitor, may play a key role in the degradation of egg yolk proteins. Other authors suggested that ovoinhibitors may be related to the reproductive performance of poultry (Zhu et al., 2011).

There are literature reports on the impact of $\mathrm{OIH}$ in poultry; however, studies on the function of $\mathrm{OIH}$ in the ovaries of different duck breeds are rare. Therefore, as a candidate gene for reproductive traits, the objective of this study was to determine the expression patterns of $\mathrm{OlH}$ in the ovaries of Jingjiang ducks(JJ duck) and Shaoxing ducks (SX ducks) during the three different laying stages, and to identify the SNP of the $\mathrm{OlH}$ gene associated with laying traits. 


\section{MATERIALS AND METHODS}

\section{Animal source and samplespreparation}

The Jingjiang (JJ) and Shaoxing (SX) are two local varieties of ducks in China. The SX duck has a small body size, early maturity (about D102) and high laying performance (over 300 eggs per year) (Zhao et al., 2005). The JJ duck is an indigenous species of the Hubei Province of China, and has small body size, early maturity (about D100) and low laying performance (about 200 eggs per year) (Ding et al., 2004).

In this study, $100 \mathrm{JJ}, 100 \mathrm{SX}, 250 \mathrm{JJ}$ line I, and $226 \mathrm{JJ}$ line II female ducklings (JJ lines I and II were two lines derived from the $\mathrm{JJ}$ breed) were reared from 0 to 500daysof age. All ducks were housed in individual cages in the same room with the controlled temperature $\left(25 \pm 3^{\circ} \mathrm{C}\right)$, and fed a commercial diet during the experiments. At age at first egg, and at 180 days (egg production peak) and 500 days of age (egg production rapidly decreases at this age), six JJ ducks and six SX ducks were anesthetized with a mixture of $79 \% \mathrm{CO}_{2}$ and $21 \% \mathrm{O}_{2}$ for 1 min and then decapitated. The ovaries were collected after dissection, immediately frozen in liquid nitrogen, and stored at $-80^{\circ} \mathrm{C}$ until further analyses.

Blood samples and performance measurements (body weight at hatch, and at 4 weeks, 8 weeks, 12 weeks, and 72 weeks of age, and at first egg, age at first egg, egg weight and number of eggs laid at 72 weeks of age) were collected from the 476 ducks (JJ lines I and II). Genomic DNA was obtained according to standard procedures and stored at $-20^{\circ} \mathrm{C}$.

\section{RNA isolation and CDNA synthesis}

Total RNA was extracted using TRIZOL reagent, according to manufacturer's protocol (TaKaRa, Dalian,
China). Total RNA samples were separately pooled per duck and ovary. cDNA was synthesized from $1 \mu \mathrm{g}$ total RNA, derived from the RNA pools, using Primescript RT-reagent kit (TaKaRa, Dalian, China) with random hexamers.

\section{Real-time quantitative PCR}

All PCR primers for real-time quantitative RT-PCR are shown in Table 1. Primers were chosen to generate specific products, of around $200 \mathrm{bp}$ of $\beta$-actin and $\mathrm{OlH}$. The $\beta$-actin (EF667345) and OlH (NM_001030612) sequences for the designed primers were retrieved from GenBank. Real-time quantitative PCRs were performed in a 20- $\mu \mathrm{L}$ mixture containing $10 \mu \mathrm{L}$ 2×SYBR Green/Fluorescein qPCR Master Mix (TaKaRa, Dalian, China), $1 \mu \mathrm{L}$ template CDNA $(1 \mu \mathrm{g} / \mu \mathrm{L}), 0.4 \mu \mathrm{M}$ forward and reverse primers, and $8.2 \mu \mathrm{L} \mathrm{dd} \mathrm{H}_{2} \mathrm{O}$. Realtime quantitative PCR was performed on an $A B I 7500$ real-time quantitative $P C R$ thermal cycling instrument (Applied Biosystems, USA). The real-time quantitative PCR amplification was performed in triplicate. The cycling conditions wereas follows: 1 cycle of $50^{\circ} \mathrm{C}$ for $2 \mathrm{~min}, 95^{\circ} \mathrm{C}$ for $10 \mathrm{~min}$, followed by 40 cycles of $95^{\circ} \mathrm{C}$ for $30 \mathrm{~s}$ and $60^{\circ} \mathrm{C}$ for $30 \mathrm{~s}$.

\section{Western-Blotting Analysis}

The OlH protein from each tissue was extracted and separated in $12 \%$ gradient SDS polyacrylamide gels. The separated $\mathrm{OlH}$ protein was then transferred onto a polyvinylidene difluoride (PVDF) membrane. The specific antibody for $\mathrm{OlH}$ was used at 1:1000 dilution. All incubations were implemented in TBSE solution (containing $5 \%$ dry milk). Immunodetection was executed using Pierce chemiluminescence (Thermo, USA). The signal intensity was determined by the density measurement method.

Table 1 - Primers used for real time quantitative PCR and SNP detecting of duck OIH gene

\begin{tabular}{|c|c|c|c|c|}
\hline Primer name & Product size (bp) & Primer sequence $\left(5^{\prime}-3^{\prime}\right)$ & Amplified region & $\begin{array}{c}\text { Annealing } \\
\text { Temperature } \mathrm{X}\left({ }^{\circ} \mathrm{C}\right) \\
\end{array}$ \\
\hline \multirow{2}{*}{$\beta$-actin } & \multirow{2}{*}{150} & F-5'-ACGGTGCTGTCTGGTGGTA-3 & \multirow[b]{2}{*}{ - } & \multirow{2}{*}{60} \\
\hline & & R-5'-TGTCTGACATGGGAGAGCAG-3 & & \\
\hline \multirow{2}{*}{$\mathrm{OlH}$} & \multirow{2}{*}{243} & R:5'- TGCGTTGCAGAAGAAACATC-3' & \multirow[b]{2}{*}{ - } & \multirow{2}{*}{60} \\
\hline & & R:5'- TGCGTTGCAGAAGAAACATC-3' & & \\
\hline \multirow{2}{*}{ P1 } & \multirow{2}{*}{668} & F: CAGATGGCTCCACATACAG & \multirow{2}{*}{ exon3-5 } & \multirow{2}{*}{53} \\
\hline & & R: GCAAATCCCACATTCGTT & & \\
\hline \multirow[b]{2}{*}{ P2 } & \multirow[b]{2}{*}{579} & F: GTAGCCTGCCCAAGGATTC & \multirow{2}{*}{ intron 5} & \multirow{2}{*}{55} \\
\hline & & R: CCGATCTCCAGCTTGCATT & & \\
\hline P3 & 569 & $\begin{array}{l}\text { F: CGGCACCGATGGTTTCAC } \\
\text { R: ATCTCCTGCCTGCATTTT }\end{array}$ & intron 7 & 54 \\
\hline \multirow{2}{*}{ P4 } & \multirow{2}{*}{718} & F: AAAATGCAGGCAGGAGAT & \multirow{2}{*}{ intron 9} & \multirow{2}{*}{51} \\
\hline & & R: TTTCTTGTTGGGTATTGA & & \\
\hline P5 & 974 & $\begin{array}{l}\text { F: AAGAACGGAAGATGTGAAG } \\
\text { R: TAACACGCTGCCATACTCA }\end{array}$ & exon $14-16$ & 52 \\
\hline
\end{tabular}


Wu Y, Liang $\mathrm{H}$, Zhang $\mathrm{H}$, Pi JS, Pan AL, Shen J, Pu YJ, Du JP
The Differential Expression and Snp Analysis of the Ovoinhibitor Gene in the Ovaries of Laying Duck Breeds (Anas Platyrhynchos)

\section{PCR amplification, SNP identification, and genotyping}

According to duck $\mathrm{OlH}$ gene sequences (NC_006100), five pairs of primers (shown in Table 1) were designed to amplify the $\mathrm{OIH}$ gene exon3 to16 regions and to detect their SNP.

The PCR assays were performed in an Eppendorf Mastercycler gradient (Eppendorf, Germany). The final volume was $15 \mu \mathrm{L}$, and contained $7.5 \mu \mathrm{L} 2 \times$ Taq PCR mix (Dongsheng, Guangdong, China), 10 pM of each primer, and $50 \mathrm{ng}$ genomic DNA. The cycling condition consisted of an initial denaturation step at $95^{\circ} \mathrm{C}$ for 4 min followed by 35 cycles of $95^{\circ} \mathrm{C}$ for $30 \mathrm{~s}$, annealing at $\mathrm{X}^{\circ} \mathrm{C}$ (Table 1) for $35 \mathrm{~s}, 72{ }^{\circ} \mathrm{C}$ for $30 \mathrm{~s}$, and a final extension at $72{ }^{\circ} \mathrm{C} 10 \mathrm{~min}$.

Genomic DNA of JJ lines I and II was used as template and the sequenced sequences from different samples were aligned to search for base variations.

The PCR-RFLP was used to analyze the polymorphisms in duck OIH. It was performed by mixing $8 \mu \mathrm{L}$ of the PCR products (with primer exon 5-6), $10 \cup$ Taq I restriction enzyme (New England Biolabs, USA) and $1 \mu \mathrm{L} 10 \times$ reaction buffer. The mixtures were incubated at $37^{\circ} \mathrm{C}$ for $12 \mathrm{~h}$ and separated at $150 \mathrm{v}$ in 3\% agarose gel.

\section{Statistical analyses}

The real-time quantitative PCR data were calculated using the $2^{-\Delta \Delta C t}$ comparative CT method. The results are expressed as mean \pm standard deviation. Ct values were tested for normality (Kolmogorov-Smirnov test) prior to analysis. Statistical analysis of data was performed by one-way analysis of variance followed by LSD post-hoc test.

The gene frequencies were determined for each population by direct counting. Hardy-Weinberg equilibrium (HWE) was tested using $\chi^{2}$-test of PopGene32 (version 3.2) in each population. The association analyses between $\mathrm{OIH}$ genotypes and laying traits (including body weight at hatch, and 4, $8,12,72$ weeks of age, weight at first egg, age at first egg, egg weight and egg number at72 weeks of age) were analyzed according to the general linear model (GLM) procedure of the software SPSS (version 18.0). All analyses were performed first using a full animal model, and next using a reduced animal model. The full animal model included fixed effects of SNP genotypes, populations, and random effects (including permanent environment, animal and residual). The effect associated with populations was not matched in the linear model, and the preliminary analyses indicated that this effect had no significant influence on variability of the traits in the analyzed populations.

Therefore, the following reduced linear model was used for final analysis:

$$
Y_{i j}=\mu+G_{i}+e_{i j}
$$

Where $Y_{i j}$ is the trait measured on each of ijth animal; $\mu$ was the overall population means; $G_{i}$ is the fixed effect associated with the ith genotype; and $e_{i j}$ is the random error. The least square analysis was used to determine the difference between genotypes.

\section{RESULTS}

\section{Expression of duck OlH}

The mRNA expression of $\mathrm{OlH}$ in ovaries of $\mathrm{JJ}$ and SX ducks collected at the three different ages was determined by real-time quantitative PCR. As Figure 1 shows, the mRNA of OIH was detected in all examined ovary samples. The relative expression of the OIH mRNA transcript in the ovaries continuously increased during the laying period (from the first egg to 500 days of age). The relative expression level of OIH mRNA in the ovaries $(p<0.05)$ was significantly different between the two breeds from at age at first egg and 180 days of age, but not at 500 days of age $(p>0.05)$. Furthermore, in the ovaries, the relative mRNA expression of $\mathrm{OlH}$ between age at $1^{\text {st }}$ egg and 180 days of age was lower in JJ ducks compared with SX ducks, but was higher in in JJ ducks than in SX ducks at 500 days of age.

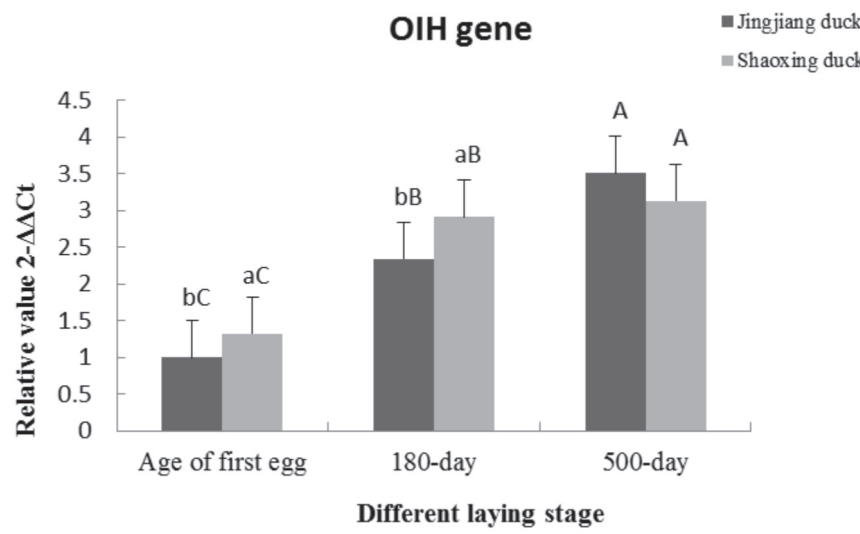

Figure 1 - Development changes of the relative expression levels of OIH mRNA in the ovaries of Jingjiang and Shaoxing ducks. Note: Different lowercase letters ( $a$ and $b$ ) indicate significant difference $(p<0.05)$ between Jingjiang and Shaoxing ducks; different uppercase letters (A, B and C) indicate significant age of first egg, 180-day and 500-day differences $(p<0.05)$ in the same duck population.

The method of Western-Blot was used to examine whether the $\mathrm{OIH}$ protein could be detected in ovary samples. The predicted duck $\mathrm{OlH}$ protein weight was $49 \mathrm{kDa}$. The results are shown in Figure 2. The $\mathrm{OIH}$ protein was detected in all ovaries of both SX and JJ 
Wu Y, Liang $\mathrm{H}$, Zhang $\mathrm{H}$, Pi JS, Pan AL, Shen J, Pu YJ, Du JP
The Differential Expression and Snp Analysis of the Ovoinhibitor Gene in the Ovaries of Laying Duck Breeds (Anas Platyrhynchos) ducks, and the results did not show any significant differences ( $p>0.05)$ in them RNA expression of $\mathrm{OlH}$ between the two breeds at any of the evaluated periods. This may be probably due to the fact that part of the mRNA of OlH was not translated into the protein in the ovaries at the different stages.
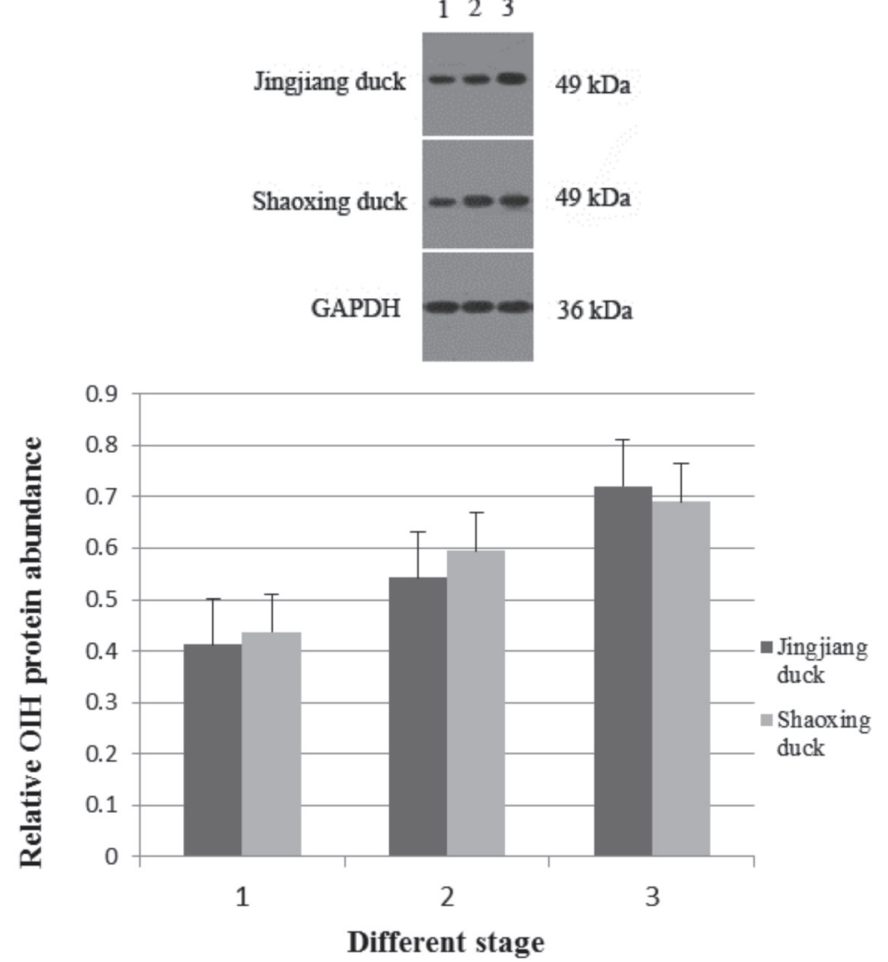

Figure $\mathbf{2}$-Western-blot results of $\mathrm{OlH}$ in the ovaries of Jingjiang and Shaoxing ducks. Note: 1 is stage of age at first egg; 2 is stage of 180 days of age; 3 is stage of 500 days of age; (a) Western blot results of $\mathrm{OlH}$; (b) relative expression of $\mathrm{OlH}$ in the ovaries of $\mathrm{JJ}$ and SX ducks

\section{Identified SNP}

The sequences amplified with all primers (P1, P2, P3, P4 and P5ofexon 3-5, exon 5-6, intron 7, intron 9 and exon 14-16) were aligned between JJ duck lines 1 and 2. No mutations were detected in exon 3-5, intron 7, intron 9, or exon 14-16. There was one variation locus in exon 5-6, $G \rightarrow A$ at the 389-nucleotide position $(389 \mathrm{G}>\mathrm{A})$, which was detected by restriction endonucleases Taql. This variation was a synonymous mutation and did not cause any amino acid changes. This SNP was detected by PCR-RFLP using the amplification product of exon 5-6. We submitted the sequences of two homozygotes of exon 5-6 to GenBank, and gain accession numbers KC977993 (for the GG genotype) and KC977994 (for the AA genotype).

As Figure 3 shows, the $G$ to Amutation at locus 389 expressed three genotypes: GG, GA and AA, and the partial sequences of three genotypes are shown in Figure 4.

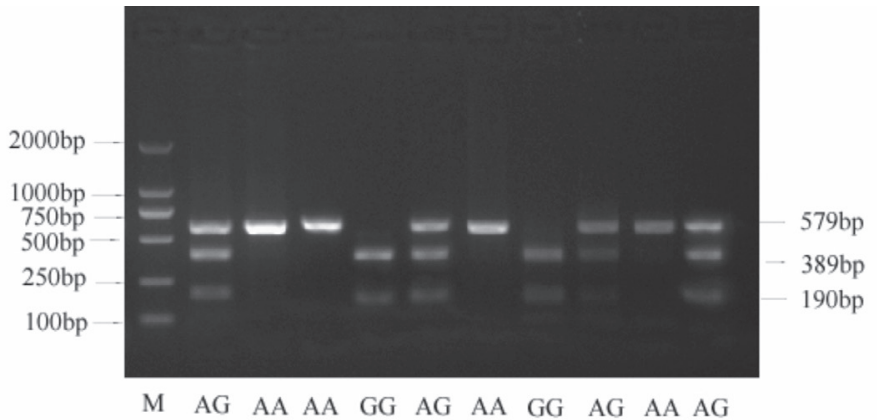

Figure 3 - PCR-RFLP band pattern on a 3\% agarose gel. Genotype AA: 579 bp; genotype AG: 579bp + 389 bp +190 bp; genotype GG: 389 bp + 190 bp
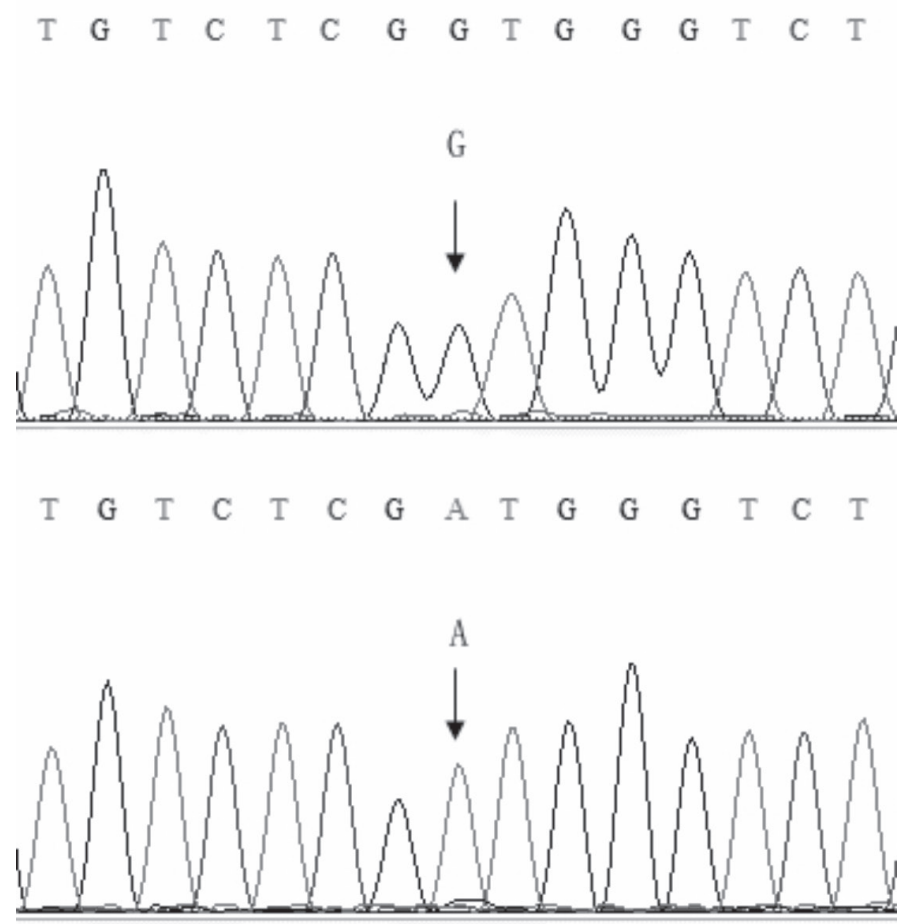

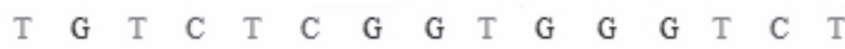

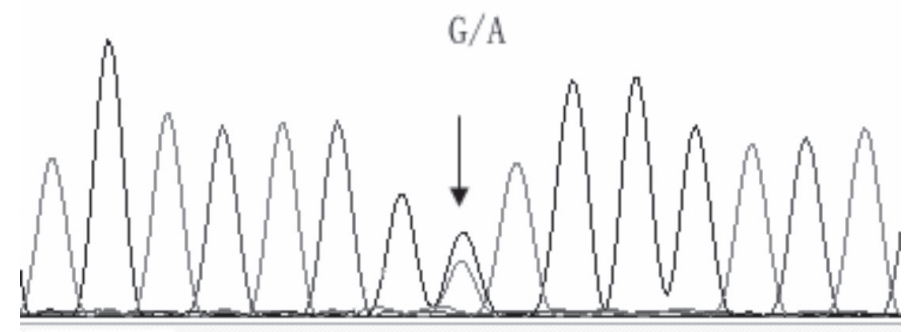

Figure 4 - Sequencing shows that the sequence amplified by primer intron 5 contains the $389 \mathrm{G}>\mathrm{A}$ mutation. AA genotype contains allele $\mathrm{A}$ at 389th position; $\mathrm{GG}$ genotype contains allele $G$ at 389th position; $A G$ genotype contains both $A$ allele and $G$ allele at 389th position.

\section{Allele and genotype of OIH gene exon5-6}

The frequencies of allele and genotypes of $\mathrm{OlH}$ gene exon 5-6 in the two duck populations are shown Table 2. In the 389 locus of exon 5-6, the G allele was 
Table 2 - Gene and genotype distribution in exon 5-6 locus of OIH gene in two duck populations

\begin{tabular}{|c|c|c|c|c|c|c|c|}
\hline \multirow{2}{*}{ Population } & \multirow{2}{*}{ Number } & \multicolumn{3}{|c|}{ Genetype frequencies } & \multicolumn{2}{|c|}{ Gene frequencies } & \multirow[t]{2}{*}{$\chi 2$ (HWE) } \\
\hline & & AA & GG & $A G$ & A & $\mathrm{G}$ & \\
\hline JJ duck Line I & 250 & 0.1280 & 0.5200 & 0.3520 & 0.3040 & 0.6960 & 3.7174 \\
\hline JJ duck Line II & 226 & 0.1770 & 0.3186 & 0.5044 & 0.3363 & 0.6637 & 9.5740 ** \\
\hline
\end{tabular}

Note: $\chi 2$ (HWE): Hardy-Weinberg equilibrium $\chi 2$ value; ${ }^{* *}$ showed that $p<0.01$.

the preponderant allele in the evaluated populations, and the JJ duck line II population deviated from HardyWeinberg equilibrium (HWE) $(p<0.01)$.

\section{Association analysis of OIH gene exon 5-6}

We analyzed the association of the SNP with laying traits of two duck populations ( $\mathrm{J}$ lines I and II). The results are presented in Table 3. In JJ duck line I, heterozygotes $(A G)$ were significantly younger at first egg than those with genotypes $A A$ and $G G$ $(p<0.05)$, and egg number at 72 weeks of age was significantly different among the $A G, G G$ and $A A$ genotypes $(p<0.05)$.In JJ duck line II, the genotype AA was significantly heavier at hatch, and produced a higher number of eggs at 72 weeks of age $(p<0.05)$ than genotypes GG and AG. Moreover, body weight at first egg of the genotype $G G$ was significantly lower compared with genotype AG $(p<0.05)$.

Table 3 - Least square means and standard errors of the laying traits in two duck populations

\begin{tabular}{|c|c|c|c|c|c|c|}
\hline \multirow{2}{*}{ Traits } & \multicolumn{3}{|c|}{ JJ duck line I (Mean \pm S.E.) } & \multicolumn{3}{|c|}{ JJ duck line II (Mean \pm S.E.) } \\
\hline & AA $(n=34)$ & GG $(n=130)$ & $A G(n=86)$ & AA $(n=34)$ & GG $(n=112)$ & $A G(n=80)$ \\
\hline Body weight of hatch (g) & $44.01 \pm 0.79$ & $44.18 \pm 0.58$ & $43.31 \pm 0.67$ & $47.09 \pm 0.53 a$ & $41.42 \pm 0.71 b$ & $40.47 \pm 0.68 b$ \\
\hline Weight at 4 weeks (g) & $508.34 \pm 15.35$ & $505.71 \pm 9.59$ & $491.56 \pm 12.16$ & $546.26 \pm 13.03$ & $535.74 \pm 13.42$ & $530.70 \pm 13.87$ \\
\hline Weight at 8 weeks (g) & $886.22 \pm 22.04$ & $858.30 \pm 14.23$ & $860.23 \pm 20.57$ & $912.86 \pm 34.17$ & $865.99 \pm 20.56$ & $904.77 \pm 23.41$ \\
\hline Weight at 12 weeks (g) & $1263.31 \pm 47.66$ & $1218.16 \pm 24.69$ & $1234.97 \pm 32.01$ & $1316.46 \pm 41.31$ & $1252.14 \pm 26.84$ & $1327.73 \pm 31.85$ \\
\hline Weight at first egg (g) & $1408.85 \pm 43.99$ & $1364.9 \pm 24.02$ & $1427.88 \pm 23.30$ & $1327.73 \pm 18.94 a b$ & $1332.22 \pm 24.72 b$ & $1459.04 \pm 23.43 a$ \\
\hline Age at first egg (d) & $149.00 \pm 3.88 a$ & $146.38 \pm 2.09 a$ & $136.00 \pm 1.22 b$ & $137.27 \pm 2.24$ & $140.81 \pm 2.09$ & $137.15 \pm 1.09$ \\
\hline Egg weight (g) & $67.29 \pm 0.97$ & $66.26 \pm 0.85$ & $64.26 \pm 0.73$ & $65.74 \pm 1.16$ & $65.00 \pm 0.63$ & $66.02 \pm 0.88$ \\
\hline Weight 72 weeks (g) & $1404.58 \pm 34.31$ & $1402.55 \pm 27.03$ & $1358.33 \pm 28.75$ & $1398.89 \pm 57.88$ & $1697.08 \pm 30.24$ & $1410.96 \pm 31.03$ \\
\hline Egg number at 72 weeks & $199.69 \pm 8.13 c$ & $268.22 \pm 7.68 b$ & $315.79 \pm 7.28 a$ & $268.81 \pm 7.02 b$ & $306.14 \pm 5.61 a$ & $307.92 \pm 9.14 a$ \\
\hline
\end{tabular}

Note: Values with different superscripts within the same column differ significantly at $P<0.05(a, b, c)$; $n$ was the number of this genotypes in the population.

\section{DISCUSSION}

Ovoinhibitor $(\mathrm{OIH})$ is a Kazal-type serine inhibitor. It is the main protease inhibitor found in the chicken plasma, and known to inhibit the activity of trypsin, chymotrypsin, and elastase (Zahnley, 1975; Shechter et al. 1977; Vered et al., 1981). OIH is a three-domain protein and shares its structure with the ovomucoid protein (Moore et al., 2004). It is reported that OlH is highly expressed in the magnum and liver of chickens, followed by the uterus, egg yolk, and eggshell precursors, respectively, and that its expression increases in the liver during sexual maturation and subsequently decreases in mature hens (Bourin et al., 2011). However, to date, the expression pattern of $\mathrm{OlH}$ in ovaries of laying ducks has not been not detected. Real-timequantitative PCR has become a standard method to measure gene expression by evaluating the amount of mRNA produced (Ong et al., 2002). So, in this study, the expression of OlH mRNA in the ovaries at age at first egg, and 180 days and 500 days of age were researched using real-time quantitative PCR.
In this study, OIH mRNA expression level increased from age at $1^{\text {st }}$ egg until 500 days of age in the ovaries of both JJ and SX ducks, and was significantly different between age at first egg and 180 days. These results are inconsistent with the $\mathrm{OlH}$ expression levels reported in the liver of mature chickens (Bourin, et al., 2011), and suggest that the profile of $\mathrm{OlH}$ expression is different among species and tissues.

SX and JJ ducks are both local Chinese breeds, with SX ducks presenting high egg production and JJ ducks low egg production. In this study, we found that the OIH mRNA expression in JJ ducks was lower than in SX ducks at age at first egg and 180 days of age, whereas at 500 days of age, the OIH mRNA expression in $\mathrm{JJ}$ ducks was higher than in SX ducks. In addition, the Western-Blot results have showed similar OIH mRNA expression pattern. These results indicate that $\mathrm{OIH}$ is closely related to the laying performance of ducks and may play an important role in the ovary during the egg-laying period.

The candidate gene method is a very powerful method to detect associations of gene polymorphisms 
with economic traits in farm animals (Schwerin, 2003). In view of the function of $\mathrm{OlH}$, in this research, the $\mathrm{OlH}$ gene was chosen as a candidate gene to study the association between gene polymorphisms and laying traits in ducks.

Goliasova \& Wolf (2004) reported that in populations subjected to selection, in general, deviations of genotype frequencies from the Hardy-Weinberg equilibrium are expected in some loci that impact traits under selection. The results of this study indicate that the JJ duck II population deviated from the HardyWeinberg equilibrium (HWE) $(p<0.05)$ for the $\mathrm{OlH}$ gene. One of the reasons may be that the evaluated population was subjected to intensive selection during commercial breeding.

In this study, one novel mutation was found in exon 5-6 of the OlH gene using PCR-RFLP methods. We analyzed the associations between genotypes and laying traits, including hatching weight, weight at 4 , 8,12, and 72 weeksof age, weight at first egg, age at first egg, egg weight, egg number at 72 weeks of age. The results indicated the AG genotype presented inferior hatching weight and superior weight at first egg, age at first egg, and egg number at72 weeks of age. This is in accordance with Wang (2015), who suggested that the SNP of OIH gene introns 10 and 11 may be related with some laying traits in ducks. Therefore, we postulate that the OIH gene may have a quantitative trait locus (QTL), which controls some laying traits in the exon 5-6,and that the genotype AG may be used as a SNP marker for inferior hatch weight and superior weight at first egg, age at first egg, and egg number at 72 weeks of age. Nevertheless, we concluded that, in order to prove the associations of the mutation of the $\mathrm{OlH}$ gene exon 5-6, more samples and further analyses should be carried out.

\section{ACKNOWLEDGEMENTS}

This study was supported by the open project of Animal Embryo and Molecular Breeding of Hubei Key Laboratory (Grant No. 2017ZD141) and Technical innovation special project of Hubei Province (Grant No. 2016ABA117).

\section{REFERENCES}

Bourin M, Gautron J, Berges M, Attucci S, Le Blay G, Labas V, et al. Antimicrobial potential of egg yolk ovoinhibitor, a multidomain Kazallike inhibitor of chicken egg. Journal of Agricultural and Food Chemistry 2011;59(23):12368-12374.
Ding SH, Chen HS, Liu JP, Zhao SQ. Breeds of livestock and poultry in Hube province. Hubei: Science and Technology Press; 2004. p.176-179

Gao D, Qiu N, Liu Y, Ma M. Comparative proteome analysis of egg yolk plasma proteins during storage. Journal of the Science of Food \& Agriculture 2017;97(3):2392-2400.

Goliasova E, Wolf J. Impact of the ESR gene on litter size and production traits in Czech Large White pigs. Animal Genetic 2004;35(4):293-297.

Kinoshita K, Shimogiri T, Okamoto S, Yoshizawa K, Mannen H, Ibrahim HR, et al. Linkage mapping of chicken ovoinhibitor and ovomucoid genes to chromosome 13. Animal Genetic 2004;35(4):356-358.

Laskowski M Jr, Kato I. Protein inhibitors of proteinases. Annual Review of Biochemistry 1980;49:593-626.

Liu WH, Means GE, Feeney RE. The inhibitory properties of avian ovoinhibitors against proteolytic enzymes. Biochimica et Biophysica Acta 1971;229:176-285.

Moore RW, Hargis BM, Porter TE, Caldwell DY, Oubre CM, Vandesande $\mathrm{F}$, et al. Ovoinhibitor in the chicken bursa of Fabricius:identification, isolation, and localization. Cell \& Tissue Research 2004;317(3):247251.

Ong YL, Irvine A. Quantitative real-time PCR: a critique of method and practical considerations. Hematology 2002;7:59-67.

Schwerin M. Functional genomics: new possibilities for animal breeding and husbandry. Archiv fur Tierzucht-archives of Animal Breeding 2003;46:89-93. Special issue

Shechter $Y$, Burnstein $Y$, Gertler A. Effect of oxidation of methionine residues in chicken ovoinhibitor on its inhibitory activities against trypsin, chymotrypsin, and elastase. Biochemistry 1997;16:992-997.

Słowińska M, Liszewska E, Nynca J, Bukowska J, Hejmej A, Bilińska B, et al. Isolation and characterization of an ovoinhibitor, a multidomain Kazallike inhibitor from Turkey (Meleagrisgallopavo) seminal plasma. Biology of Reproduction 2014;91(5):108.

Vered M, Gertler A, Burstein Y. Inhibition of porcine elastase II by chicken ovoinhibitor. International Journal of Peptide and Protein Research 1981;18:169-179

Wang M. Studies on polymoprhisms of duck $\mathrm{OlH}$ and $\mathrm{FSH} \beta$ gene and their associations with egg performance [thesis].Wuhan (CHN): Huazhong Agricultural University; 2015. p.17-20.

Zahnley JC. Preferred binding of bovine and porcine trypsins at two different sites on chicken ovoinhibitor. Reduced dissociation of mixed trypsin complexes .Journal of Biological Chemistry 1977;250:7879-7884.

Zhao RQ, Zhou YC, Ni YD, Lu LZ, Tao ZR, Chen WH, et al. Effect of daidzein on egg-laying performance in SX duck breeders during different stages of the egg production cycle. British Poultry Science 2005;46(2):175181.

Zhu K, Chen Q, Zhang XZ, Wang QS, Tu YY, Pan YC, et al. Association analysis of PRL, OVR, OIH and GnRHR gene's polymorphisms with laying performances in Hy-line Chicken. China Poultry 2011;33(19):3135. 